\title{
Marine algal natural products with anti-oxidative, anti-inflammatory, and anti-cancer properties
}

\author{
Jin-Ching Lee ${ }^{1}$, Ming-Feng Hou ${ }^{2,3,4}$, Hurng-Wern Huang ${ }^{5}$, Fang-Rong Chang ${ }^{6}$, Chi-Chen Yeh ${ }^{6}$, \\ Jen-Yang Tang ${ }^{4,7,8^{*}}$ and Hsueh-Wei Chang ${ }^{4,6,9^{*}}$
}

\begin{abstract}
For their various bioactivities, biomaterials derived from marine algae are important ingredients in many products, such as cosmetics and drugs for treating cancer and other diseases. This mini-review comprehensively compares the bioactivities and biological functions of biomaterials from red, green, brown, and blue-green algae. The antioxidative effects and bioactivities of several different crude extracts of algae have been evaluated both in vitro and in vivo. Natural products derived from marine algae protect cells by modulating the effects of oxidative stress. Because oxidative stress plays important roles in inflammatory reactions and in carcinogenesis, marine algal natural products have potential for use in anti-cancer and anti-inflammatory drugs.
\end{abstract}

Keywords: Algae, ROS, Antioxidant, Inflammation, Antinociceptive, Anti-cancer

\section{Introduction}

Various bioactive compounds from marine organisms have been experimentally tested to comprehensively study the biological effects of recently developed drugs [1]. Marine algae are rich in dietary fiber, minerals, lipids, proteins, omega-3 fatty acids, essential amino acids, polysaccharides, and vitamins $\mathrm{A}, \mathrm{B}, \mathrm{C}$, and $\mathrm{E}$ [2-6]. Studies on the bioactivities of marine algae have revealed numerous health-promoting effects, including anti-oxidative, anti-inflammatory, antimicrobial, and anti-cancer effects. This mini-review will evaluate the specific effects found with red (Rhodophyta) [7-11], green (Chlorophyta) [12,13], brown (Phaeophyta) [14], and blue-green [15-18] species of marine algae. Figure 1 provides a brief overview of this mini-review.

\section{Bioactive components of marine algae}

The versatility of the functions of algae may derive from their abundant bioactive metabolites $[19,20]$. Well-documented bioactive metabolites of marine algae [21] include brominated phenols [20], brominated oxygen heterocyclics, nitrogen heterocyclics,

\footnotetext{
*Correspondence: reyata@kmu.edu.tw; changhw@kmu.edu.tw

${ }^{4}$ Cancer Center, Kaohsiung Medical University Hospital, Kaohsiung Medical

University, Kaohsiung, Taiwan

${ }^{7}$ Department of Radiation Oncology, Faculty of Medicine, College of

Medicine, Kaohsiung Medical University, Kaohsiung, Taiwan

Full list of author information is available at the end of the article
}

kainic acids, guanidine derivatives, phenazine derivatives, amino acids and amines, sterols [22], sulfated polysaccharides [4,23,24], and prostaglandins [25]. Fucoxanthin, a type of xanthophyll and an accessory pigment in the chloroplasts of algae, has also shown various beneficial effects [26]. However, not all species of algae have health-promoting properties, as some are known to produce toxic metabolites that cause neurodegenerative disorders [27].

\section{Cultivation environment of marine algae}

The cultivation environment may affect the bioactive metabolite content of an alga. For example, changes in cultivation conditions, such as spatial variations, can cause changes in the polyphenolic content in the Ascophyllum nodosum species of brown algae [28]. Additionally, in three green algae species, Capsosiphon fulvescens, Enteromorpha prolifera, and Codium fragile, bioactive metabolite content varies with the time of harvest [29]. Sulfated polysaccharides of the red alga Delesseria sanguinea (Hudson) Lamouroux can be collected throughout the year, although collection during the spring is optimal [30]. 


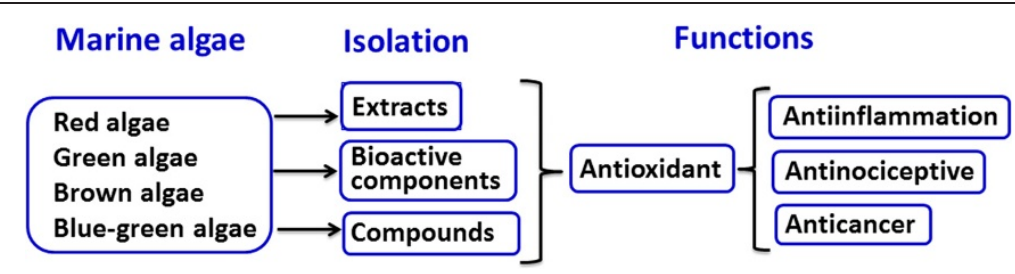

Figure 1 Summary of marine algal natural products with anti-oxidative, anti-inflammatory, anti-nociceptive, and anti-cancer properties.

\section{Antioxidant activities and bioactive components of marine algae extracts}

Antioxidant activities have been identified in various marine algae, including red, green, and brown algae species [31], and in their enzymatic extracts [32-34]. The antioxidant properties of extracts and bioactive components of four common marine algae are discussed here.

\section{Red algae}

Ethanol extracts of the Callophyllis japonica [35] and Gracilaria tenuistipitata [36] species of red algae reportedly have antioxidant effects. For example, ethanol extracts of $C$. japonica suppressed $\mathrm{H}_{2} \mathrm{O}_{2}$-induced cellular apoptosis and activated cellular antioxidant enzymes [35]. Experiments performed with the H1299 cell line showed that treatment with an aqueous extract of $G$. tenuistipitata enhanced the recovery of these cells from $\mathrm{H}_{2} \mathrm{O}_{2}$-induced DNA damage, counteracts cellular proliferation, and induced G2/M arrest [36].

\section{Green algae}

Free-radical-scavenging assays using green algae revealed antioxidant properties for the sesquiterpenoids from Ulva fasciata Delile [37]. Ulva lactuca is rich in flavonoids and has potent antioxidant properties [38]. Data obtained from animal model studies has started to shed light on the fact that the free radical scavenging effects of a hot water extract of Ulva reticulate [39] reduced hepatic oxidative stress.

\section{Brown algae}

Assays of 2,2-diphenyl-1-picrylhydrazyl (DPPH)-radical scavenging have revealed antioxidant activities for the phlorotannins from the Eisenia bicyclis, Ecklonia cava, and Ecklonia kurome species of brown algae [40]. Methanol extracts of Fucus vesiculosus and $F$. serratus are known to protect Caco- 2 cells from DNA damage induced by $\mathrm{H}_{2} \mathrm{O}_{2}$ [41], but not from DNA damage induced by tert-butyl hydroperoxide [42]. Methanol extracts of Pelvetia canaliculata inhibited $\mathrm{H}_{2} \mathrm{O}_{2}$-induced superoxide dismutase depletion in Caco-2 cells [41].

\section{Blue-green algae}

Analyses of DPPH radical scavenging activity have revealed antioxidant effects of a methanol extract of the Anabaena species of blue-green algae [43]. Ascorbate/ iron $/ \mathrm{H}_{2} \mathrm{O}_{2}$ assays have also revealed antioxidant effects of phycobiliprotein phycocyanin in a Spirulina platensis extract [44]. To date, the antinociceptive properties of blue-green algae have been less thoroughly investigated.

\section{Anti-inflammatory and antinociceptive properties of marine algae extracts and components}

Oxidative stress plays important roles in endothelial dysfunction [45], lung disease [46], gastrointestinal dysfunction [47], and atherosclerosis [48], all of which involve inflammatory reactions. Many marine natural products that contain antioxidants are known to have anti-inflammatory effects [49-51]. Examples of the antiinflammatory and antinociceptive properties identified in extracts and bioactive components of different marine algae are discussed here.

\section{Red algae}

The bioactivities of the Gracilaria spp. of red algae have been thoroughly reviewed [52]. However, antiinflammatory properties have been reported for only two species, G. verrucosa and G. textorii. Evidence of anti-inflammatory properties in other species of red algae is also increasing. For example, an aqueous extract of G. tenuistipitata suppressed virus-induced inflammation [53], a polysaccharide from Porphyridium sp. inhibited the replication of retroviruses [54], and an ethanol extract of Polyopes affinis suppressed asthmatic reactions [55]. The anti-inflammatory effects of a methanol extract of Neorhodomela aculeata in neurological diseases included inhibiting cellular reactive oxygen species (ROS) generation, $\mathrm{H}_{2} \mathrm{O}_{2}$-induced lipid peroxidation, and inducible nitric oxide synthase [56].

The anti-inflammatory effects of Laurencia glanduliferaderived neorogioltriol, a tricyclic brominated diterpenoid, have been demonstrated for cells that were stimulated by lipopolysaccharide (LPS) [57]. Two Laurencia obtuse-derived $\mathrm{C} 15$ acetogenins, (12Z)-cis-maneonene-D and (12E)cis-maneonene-E, mediated the apoptosis of neutrophils during the progression of inflammatory responses [58]. A 
Porphyra yezoensis glycoprotein exhibited anti-inflammatory effects in LPS -stimulated macrophages [59]. Two enone fatty acids of Gracilaria verrucosa, (E)-10Oxooctadec-8-enoic acid and (E)-9-Oxooctadec-10enoic acid, inhibited the production of the inflammatory markers nitric oxide, TNF- $\alpha$, and IL-6 [60]. Multi-mineral aquamin derived from Lithothamnion corallioides had anti-inflammatory effects on glial-enriched primary cultures of rat cortex [61]. Sulfated polysaccharides from Delesseria sanguinea (Hudson) Lamouroux also exhibited anti-inflammatory effects [30].

Some red algae species exhibit both antinociceptive and anti-inflammatory effects. For example, a methanol extract of Bryothamnion triquetrum [62] had both antinociceptive and anti-inflammatory properties in experiments that used Swiss mice. Antinociceptive activity was examined using an acetic acid-induced writhing test, a hot-plate test, and glutamate-/formalin-induced nociception. Anti-inflammatory effects were assessed by zymosan A-induced peritonitis analysis. Antinociceptive and anti-inflammatory activities have also been reported for a sulfated polysaccharide fraction from Gracilaria caudate [63], a galactan from Gelidium crinale [64], a mucin-binding agglutinin from Hypnea cervicornis [65], and a lectin from Pterocladiella capillacea [66].

\section{Green algae}

Crude extracts and purified components of some green algae species are also known to have anti-inflammatory properties. For example, Dunaliella bardawil is rich in antioxidant beta-carotene. Studies with rats have confirmed its protective effects against acetic acid-induced small bowel inflammation [67]. Methanol extracts of Ulva conglobata and $U$. lactuca have shown anti-inflammatory effects in experiments that used a murine hippocampal HT22 cell line [68] and rats [69]. Studies of purified components include one on lycopene from Chlorella marina, which confirmed the anti-inflammatory effects of lycopene in a rat model of arthritis [70]. A sheep model of inflammation-induced cytokine production demonstrated the inhibiting effects of a mixture of phytosterols from Dunaliella tertiolecta [71].

Crude extracts or purified components of some green algae species reportedly had both antinociceptive and anti-inflammatory effects. For example, several nociception models have shown both antinociceptive and antiinflammatory activities of aqueous and methanol extracts of Caulerpa mexicana [13,72]. Both of these activities have also been demonstrated for a lectin [73] and a sulfated polysaccharide [74] from Caulerpa cupressoides.

\section{Brown algae}

A murine asthma model [75] showed that an ethanol extract of Ecklonia cava reduced allergic airway reactions and inflammation and inhibited LPS-induced inflammation in human endothelial cells [76]. An ethanol extract of Ishige okamurae also showed anti-inflammatory effects [77].

Studies of sulfated polysaccharides include animal models $[78,79]$, which confirmed the anti-inflammatory effects of a sulfated galactofucan from Lobophora variegata. Alginic acid, an anionic polysaccharide in Sargassum wightii, exhibited anti-inflammatory effects in a rat study of adjuvant-induced arthritis [80]. Fucoidan is known to enhance the probiotic effects of Lactic acid bacteria (LAB) by immunomodulation of an anti-allergic response [81]. Fucans from Lobophora variegata [82], Sargassum vulgare [83], and Spatoglossum schroederi [84] also have both antiinflammatory and antinociceptive effects.

Additionally, anti-inflammatory effects have been demonstrated for the Myagropsis myagroides-dervied carotenoid fucoxanthin [85], for Eisenia bicyclis, Ecklonia cava- and Ecklonia kurome-derived polyphenol phlorotannins [86], and for Sargassum siliquastrum-derived sargachromanol G [87]. Phloroglucinol, a monomer of phlorotannins that is abundant in brown algae, reportedly had an anti-oxidative stress effect and inhibited the production of inflammatory mediators in LPS-stimulated cells [88].

\section{Blue-green algae}

Blue-green algae have well-documented protective effects against viral and bacterial infections, cancer, allergies, diabetes, inflammation, and hyperlipidemia [16]. For example, the spirulina alga had anti-oxidative and anti-inflammatory effects when assessed using a non-alcoholic steatohepatitis model [15]. C-phycocyanin [17], a biliprotein isolated from Spirulina platensis, suppressed inflammation by inhibiting the production of pro-inflammatory cytokines and by inhibiting the expressions of inducible nitric oxide synthase and cyclooxygeanase- 2 [89]. To date, the antinociceptive properties of blue-green algae have been less thoroughly investigated.

\section{Anti-cancer effects of marine algae extracts and components}

Because they modulate ROS generation, antioxidants have vital roles in carcinogenesis [90-93]. For example, occupational and environmental exposures to metals reportedly induce ROS generation and are associated with carcinogenesis [90]. ROS are also essential for inducing autophagy, which may be mediated by ataxia-telangiectasia mutated (ATM) and AMP activated protein kinase (AMPK) [91]. Sirtuin 3 (SIRT3), a deacetylase, is considered to be a mitochondrial fidelity protein that modulates ROS metabolism during responses to stress, such as those due to aging and carcinogenesis [92]. ROS overproduction may result in genomic instability and cellular damage, as well as carcinogenesis [94]. ROS signaling can also be induced by estrogen to 
increase genomic instability and promote breast cancer carcinogenesis [93].

Additionally, several drugs that may generate oxidative stress and trigger the expressions of several miRNAs and DNA damage responses have been reviewed $[95,96]$. For example, cells that were treated with ferric nitrilotriacetate could generate ROS and induce the overexpression of miRNA-34a. In contrast, miRNA-34a downregulation by a small interfering RNA may have inhibited the proliferation of HeLa and MCF7 cancer cells [97]. These results suggest that ROS and miRNAs are also involved in carcinogenesis.

Inflammation also has molecular links to carcinogenesis $[98,99]$. Therefore, pro-oxidant natural products are commonly chosen when developing anti-cancer drugs [100-102]. Examples of the anti-cancer properties of extracts and bioactive components of four marine algae are discussed here.

\section{Red algae}

Aqueous extracts of Gracilaria corticata [103] and Sargassum oligocystum [104] inhibited the proliferation of human leukemic cell lines. Both ethanol [11] and methanol [105] extracts of Gracilaria tenuistipitata reportedly had anti-proliferative effects on Ca9-22 oral cancer cells and were involved in cellular apoptosis, DNA damage, and oxidative stress. Similarly, caspase-dependent apoptosis induced by a methanol extract of Plocamium telfairiae has been demonstrated using HT-29 colon cancer cells [106].

\section{Green algae}

Among green algae, a hot water extract of Capsosiphon fulvescens that contained polysaccharides induced the apoptosis of gastric cancer cells [107] via the PI3K/Akt pathway $[108,109]$. Dimethylsulfoniopropionate, a tertiary sulfonium metabolite found in green algae and other algae species, exhibited anti-cancer effects in mice with Ehrlich ascites carcinoma [110].

\section{Brown algae}

Studies of brown algae have shown that glycoproteins from Laminaria japonica [111] and fucoidans from Sargassum hornery, Eclonia cava, and Costaria costata [112] had anti-cancer effects on human colon cancer cells. Heterofucans from Sargassum filipendula exhibited anti-proliferative effects on cervical, prostate, and liver cancer cells [113]. A carotenoid fucoxanthin cold inhibit the growth of LNCap prostate cancer cells by arresting these cells in the G1 phase via the GDD45A and SAPK/ JNK pathways [114].

\section{Blue-green algae}

Studies of blue-green algae have confirmed the anti-cancer effects of Spirulina preparations [115], recombinant glycoproteins, specifically microcystis viridis lectin (MVL) [18], and cryptophycin [116,117].

\section{Conclusion}

Marine algal natural products are rich sources of antioxidants. In fact, some marine algae are edible. The details for the fractionation of crude extracts described in this study showed that these extracts and their bioactive components had strong modulating effects on oxidative stress and on oxidative stress-related diseases and cancers. The antioxidant properties of several kinds of algae have been investigated for their anti-inflammatory, antinociceptive, and anti-cancer effects. In the future, these marine algae-derived materials/compounds will be used more often in pre-clinical studies for drug discovery.

\section{Competing interests}

The authors declare that they have no competing interests.

\section{Authors' contributions}

$\mathrm{J}-\mathrm{CL}$ did the literature search, integrated different points, and drafted the manuscript. M-FH, H-WH, F-RC, and C-CY conceived the idea and did literature search on specific points. J-YT and H-WC were involved in discussion and editing the manuscript. All authors read and approved the final manuscript.

\section{Acknowledgement}

This study was supported by a grant from the National Science Council (NSC101-2320-B-037-049), the Department of Health, Executive Yuan, Republic of China (DOH102-TD-C-111-002), the National Sun Yat-Sen University-KMU Joint Research Project (\#NSYSU-KMU 102-034).

\section{Author details}

'Department of Biotechnology, College of Life Science Kaohsiung Medical University, Kaohsiung, Taiwan. ${ }^{2}$ Institute of Clinical Medicine, Kaohsiung Medical University, Kaohsiung, Taiwan. ${ }^{3}$ Kaohsiung Municipal Ta-Tung Hospital, Kaohsiung, Taiwan. ${ }^{4}$ Cancer Center, Kaohsiung Medical University Hospital, Kaohsiung Medical University, Kaohsiung, Taiwan. Institute of Biomedical Science, National Sun Yat-Sen University, Kaohsiung, Taiwan. ${ }^{6}$ Graduate Institute of Natural Products, College of Pharmacy, Kaohsiung Medical University, Kaohsiung, Taiwan. ${ }^{7}$ Department of Radiation Oncology, Faculty of Medicine, College of Medicine, Kaohsiung Medical University, Kaohsiung, Taiwan. ${ }^{8}$ Department of Radiation Oncology, Kaohsiung Medical University Hospital, Kaohsiung, Taiwan. ${ }^{9}$ Department of Biomedical Science and Environmental Biology, Kaohsiung Medical University, Kaohsiung, Taiwan.

Received: 7 April 2013 Accepted: 27 May 2013

Published: 3 June 2013

\section{References}

1. Arif JM, Al-Hazzani AA, Kunhi M, Al-Khodairy F: Novel marine compounds: Anticancer or genotoxic? J Biomed Biotechnol 2004, 2004(2):93-98.

2. MacArtain P, Gill Cl, Brooks M, Campbell R, Rowland IR: Nutritional value of edible seaweeds. Nutr Rev 2007, 65(12 Pt 1):535-543.

3. Cerna M: Seaweed proteins and amino acids as nutraceuticals. Adv Food Nutr Res 2011, 64:297-312.

4. Misurcova L, Skrovankova S, Samek D, Ambrozova J, Machu L: Health benefits of algal polysaccharides in human nutrition. Adv Food Nutr Res 2012, 66:75-145.

5. Tabarsa M, Rezaei M, Ramezanpour Z, Waaland JR: Chemical compositions of the marine algae Gracilaria salicornia (Rhodophyta) and Ulva lactuca (Chlorophyta) as a potential food source. J Sci Food Agric 2012, 92(12):2500-2506.

6. Rajapakse N, Kim SK: Nutritional and digestive health benefits of seaweed. Adv Food Nutr Res 2011, 64:17-28. 
7. Souza BW, Cerqueira MA, Martins JT, Quintas MA, Ferreira AC, Teixeira JA, Vicente AA: Antioxidant potential of two red seaweeds from the Brazilian coasts. J Agric Food Chem 2011, 59(10):5589-5594.

8. Coura CO, de Araujo IW, Vanderlei ES, Rodrigues JA, Quindere AL, Fontes $B P$, de Queiroz IN, de Menezes DB, Bezerra MM, e Silva AA, et al: Antinociceptive and anti-inflammatory activities of sulphated polysaccharides from the red seaweed Gracilaria cornea. Basic Clin Pharmacol Toxicol 2012, 110(4):335-341.

9. Yeh ST, Lin YC, Huang CL, Chen JC: White shrimp Litopenaeus vannamei that received the hot-water extract of Gracilaria tenuistipitata showed protective innate immunity and up-regulation of gene expressions after low-salinity stress. Fish Shellfish Immunol 2010, 28(5-6):887-894.

10. Genovese G, Tedone L, Hamann MT, Morabito M: The Mediterranean red alga Asparagopsis: a source of compounds against Leishmania. Mar Drugs 2009, 7(3):361-366

11. Yeh CC, Tseng CN, Yang Jl, Huang HW, Fang Y, Tang JY, Chang FR, Chang HW: Antiproliferation and induction of apoptosis in Ca9-22 oral cancer cells by ethanolic extract of Gracilaria tenuistipitata. Molecules 2012, 17(9):10916-10927.

12. Badal S, Gallimore W, Huang G, Tzeng TR, Delgoda R: Cytotoxic and potent CYP1 inhibitors from the marine algae Cymopolia barbata. Org Med Chem Lett 2012, 2(1):21.

13. da Matta CB, de Souza ET, de Queiroz AC, de Lira DP, de Araujo MV, Cavalcante-Silva LH, de Miranda GE, de Araujo-Junior JX, Barbosa-Filho JM, de Oliveira Santos BV, et al: Antinociceptive and anti-inflammatory activity from algae of the genus Caulerpa. Mar Drugs 2011, 9(3):307-318.

14. Wijesinghe WA, Jeon YJ: Exploiting biological activities of brown seaweed Ecklonia cava for potential industrial applications: a review. Int J Food Sci Nutr 2012, 63(2):225-235

15. Pak W, Takayama F, Mine M, Nakamoto K, Kodo Y, Mankura M, Egashira T, Kawasaki H, Mori A: Anti-oxidative and anti-inflammatory effects of spirulina on rat model of non-alcoholic steatohepatitis. J Clin Biochem Nutr 2012, 51(3):227-234

16. Ku CS, Pham TX, Park Y, Kim B, Shin MS, Kang I, Lee J: Edible blue-green algae reduce the production of pro-inflammatory cytokines by inhibiting NF-kappaB pathway in macrophages and splenocytes. Biochim Biophys Acta 2013, 1830(4):2981-2988.

17. Romay C, Armesto J, Remirez D, Gonzalez R, Ledon N, Garcia I: Antioxidant and anti-inflammatory properties of C-phycocyanin from blue-green algae. Inflamm Res 1998, 47(1):36-41.

18. Li $Y$, Zhang $X$ : Recombinant Microcystis viridis lectin as a potential anticancer agent. Pharmazie 2010, 65(12):922-923.

19. Faulkner DJ: Marine natural products. Nat Prod Rep 2002, 19(1):1-48.

20. Liu M, Hansen PE, Lin X: Bromophenols in marine algae and their bioactivities. Mar Drugs 2011, 9(7):1273-1292.

21. Bhakuni DS, Rawat DS (Eds): Bioactive marine natural products. Netherlands: Springer; 2005

22. Kim SK, Ta QV: Potential beneficial effects of marine algal sterols on human health. Adv Food Nutr Res 2011, 64:191-198.

23. Jimenez-Escrig A, Gomez-Ordonez E, Ruperez P: Seaweed as a source of novel nutraceuticals: sulfated polysaccharides and peptides. Adv Food Nutr Res 2011, 64:325-337.

24. Kim SK, Li YX: Medicinal benefits of sulfated polysaccharides from sea vegetables. Adv Food Nutr Res 2011, 64:391-402.

25. Hsu BY, Tsao CY, Chiou TK, Hwang PA, Hwang DF: HPLC determination for prostaglandins from seaweed Gracilaria gigas. Food Control 2007, 18(6):639-645.

26. Kim SK, Pangestuti R: Biological activities and potential health benefits of fucoxanthin derived from marine brown algae. Adv Food Nutr Res 2011, 64:111-128.

27. Turkez $\mathrm{H}$, Gurbuz $\mathrm{H}$, Aydin E, Aslan A, Dirican E: The evaluation of the genotoxic and oxidative damage potentials of Ulothrix tenuissima (Kutz.) in vitro. Toxicol Ind Health 2012, 28(2):147-151.

28. Pavia H, Aberg P: Spatial variation in polyphenolic content of Ascophyllum nodosum (Fucales, Phaeophyta). Hydrobiologia 1996, 327:199-203.

29. Jung KJ, Jung $\mathrm{CH}$, Pyeun JH, Choi YJ: Changes of food components in Mesangi (Capsosiphon fulvescens), Gashiparae (Enteromorpha prolifera), and Cheonggak (Codium fragile) depending on harvest times. J Korean Soc Food Sci Nutr 2005, 34:687-693.
30. Grunewald N, Groth I, Alban S: Evaluation of seasonal variations of the structure and anti-inflammatory activity of sulfated polysaccharides extracted from the red alga Delesseria sanguinea (Hudson) Lamouroux (Ceramiales, Delesseriaceae). Biomacromolecules 2009, 10(5):1155-1162.

31. Kelman D, Posner EK, McDermid KJ, Tabandera NK, Wright PR, Wright AD: Antioxidant activity of Hawaiian marine algae. Mar Drugs 2012, 10(2):403-416.

32. Heo SJ, Jeon YJ, Lee J, Kim HT, Lee KW: Antioxidant effect of enzymatic hydrolyzate from a Kelp. Ecklonia cava. Algae 2003, 18(4):341-347.

33. Heo SJ, Lee KW, Song CB, Jeon YJ: Antioxidant activity of enzymatic extracts from brown seaweeds. Algae 2003, 18:71-81.

34. Heo SJ, Park EJ, Lee KW, Jeon YJ: Antioxidant activities of enzymatic extracts from brown seaweeds. Bioresour Technol 2005, 96(14):1613-1623.

35. Kang KA, Bu HD, Park DS, Go GM, Jee Y, Shin T, Hyun JW: Antioxidant activity of ethanol extract of Callophyllis japonica. Phytother Res 2005, 19(6):506-510.

36. Yang Jl, Yeh CC, Lee JC, Yi SC, Huang HW, Tseng CN, Chang HW: Aqueous extracts of the edible Gracilaria tenuistipitata are protective against $\mathrm{H}_{2} \mathrm{O}_{2}$-induced DNA damage, growth inhibition, and cell cycle arrest. Molecules 2012, 17(6):7241-7254.

37. Chakraborty K, Paulraj R: Sesquiterpenoids with free-radical-scavenging properties from marine macroalga Ulva fasciata Delile. Food Chem 2010, 122:31-41.

38. Meenakshi S, Gnanambigai DM, Mozhi ST, Arumugam M, Balasubramanian $\mathrm{T}$ : Total flavanoid and in vitro antioxidant activity of two seaweeds of Rameshwaram coast. Global J Pharmacol 2009, 3(2):59-62.

39. Balaji Raghavendra Rao H, Sathivel A, Devaki T: Antihepatotoxic nature of Ulva reticulata (Chlorophyceae) on acetaminophen-induced hepatoxicity in experimental rats. J Med Food 2004, 7(4):495-497.

40. Shibata T, Ishimaru K, Kawaguchi S, Yoshikawa H, Hama Y: Antioxidant activities of phlorotannins isolated from Japanese Laminariaceae. J App/ Phycol 2008, 20(5):705-711

41. O'Sullivan AM, O'Callaghan YC, O'Grady MN, Queguineur B, Hanniffy D, Troy DJ, Kerrya JP, O'Brien NM: In vitro and cellular antioxidant activities of seaweed extracts prepared from five brown seaweeds harvested in spring from the west coast of Ireland. Food Chem 2011, 126:1064-1070.

42. O'Sullivan AM, O'Callaghan YC, O'Grady MN, Queguineur B, Hanniffy D, Troy DJ, Kerry JP, O'Brien NM: Assessment of the ability of seaweed extracts to protect against hydrogen peroxide and tert-butyl hydroperoxide induced cellular damage in Caco-2 cells. Food Chem 2012, 134(2):1137-1140.

43. Pant G, Kumar G, Karthik L, Prasuna RG, Rao KVB: Antioxidant activity of methanolic extract of blue green algae Anabaena sp. (Nostocaceae). Eur J Exp Bio 2011, 1(1):156-162.

44. Pinero Estrada JE, Bermejo Bescos P, Villar del Fresno AM: Antioxidant activity of different fractions of Spirulina platensis protean extract. Farmaco 2001, 56(5-7):497-500.

45. Schramm A, Matusik P, Osmenda G, Guzik TJ: Targeting NADPH oxidases in vascular pharmacology. Vasc Pharmacol 2012, 56(5-6):216-231.

46. Rosanna DP, Salvatore C: Reactive oxygen species, inflammation, and lung diseases. Curr Pharm Des 2012, 18(26):3889-3900.

47. Kim YJ, Kim EH, Hahm KB: Oxidative stress in inflammation-based gastrointestinal tract diseases: challenges and opportunities. J Gastroenterol Hepatol 2012, 27(6):1004-1010.

48. Hulsmans M, Van Dooren E, Holvoet P: Mitochondrial reactive oxygen species and risk of atherosclerosis. Curr Atheroscler Rep 2012, 14(3):264-276

49. Abad MJ, Bedoya LM, Bermejo P: Natural marine anti-inflammatory products. Mini Rev Med Chem 2008, 8(8):740-754.

50. Wang W, Wang SX, Guan HS: The antiviral activities and mechanisms of marine polysaccharides: an overview. Mar Drugs 2012, 10(12):2795-2816.

51. D'Orazio N, Gammone MA, Gemello E, De Girolamo M, Cusenza S, Riccioni G: Marine bioactives: pharmacological properties and potential applications against inflammatory diseases. Mar Drugs 2012, 10(4):812-833

52. de Almeida CL, Falcao Hde S, Lima GR, Montenegro Cde A, Lira NS, de Athayde-Filho PF, Rodrigues LC, de Souza MF, Barbosa-Filho JM, Batista LM: Bioactivities from marine algae of the genus gracilaria. Int J Mol Sci 2011, 12(7):4550-4573.

53. Chen KJ, Tseng CK, Chang FR, Yang Jl, Yeh CC, Chen WC, Wu SF, Chang HW, Lee JC: Aqueous extract of the edible Gracilaria tenuistipitata inhibits 
hepatitis C viral replication via cyclooxygenase-2 suppression and reduces virus-induced inflammation. PLoS One 2013, 8(2):e57704.

54. Talyshinsky MM, Souprun YY, Huleihel MM: Anti-viral activity of red microalgal polysaccharides against retroviruses. Cancer Cell Int 2002, 2(1):8

55. Lee DS, Park WS, Heo SJ, Cha SH, Kim D, Jeon YJ, Park SG, Seo SK, Choi JS, Park SJ, et al: Polyopes affinis alleviates airway inflammation in a murine model of allergic asthma. J Biosci 2011, 36(5):869-877.

56. Lim CS, Jin DQ, Sung JY, Lee JH, Choi HG, Ha I, Han JS: Antioxidant and anti-inflammatory activities of the methanolic extract of Neorhodomela aculeate in hippocampal and microglial cells. Biol Pharm Bull 2006, 29(6):1212-1216

57. Chatter R, Ben Othman R, Rabhi S, Kladi M, Tarhouni S, Vagias C, Roussis V, Guizani-Tabbane $L$, Kharrat R: In vivo and in vitro anti-inflammatory activity of neorogioltriol, a new diterpene extracted from the red algae Laurencia glandulifera. Mar Drugs 2011, 9(7):1293-1306.

58. Ayyad SE, Al-Footy KO, Alarif WM, Sobahi TR, Bassaif SA, Makki MS, Asiri AM Al Halwani AY, Badria AF, Badria FA: Bioactive C15 acetogenins from the red alga Laurencia obtusa. Chem Pharm Bull(Tokyo) 2011, 59(10):1294-1298.

59. Shin ES, Hwang HJ, Kim IH, Nam TJ: A glycoprotein from Porphyra yezoensis produces anti-inflammatory effects in liposaccharidestimulated macrophages via the TLR4 signaling pathway. Int J Mol Med 2011, 28(5):809-815.

60. Lee HJ, Dang HT, Kang GJ, Yang EJ, Park SS, Yoon WJ, Jung JH, Kang HK, Yoo ES: Two enone fatty acids isolated from Gracilaria verrucosa suppress the production of inflammatory mediators by down-regulating NFkappaB and STAT1 activity in lipopolysaccharide-stimulated RAW 264.7 cells. Arch Pharm Res 2009, 32(3):453-462.

61. Ryan S, O'Gorman DM, Nolan YM: Evidence that the marine-derived multimineral Aquamin has anti-inflammatory effects on cortical glial-enriched cultures. Phytother Res 2011, 25(5):765-767.

62. Cavalcante-Silva LH, da Matta CB, de Araujo MV, Barbosa-Filho JM, de Lira DP, de Oliveira Santos BV, de Miranda GE, Alexandre-Moreira MS: Antinociceptive and anti-inflammatory activities of crude methanolic extract of red alga Bryothamnion triquetrum. Mar Drugs 2012, 10(9):1977-1992.

63. Chaves Lde S, Nicolau LA, Silva RO, Barros FC, Freitas AL, Aragao KS, Ribeiro Rde A, Souza MH, Barbosa AL, Medeiros JV: Antiinflammatory and antinociceptive effects in mice of a sulfated polysaccharide fraction extracted from the marine red algae Gracilaria caudata. Immunopharmacol Immunotoxicol 2013, 35(1):93-100.

64. de Sousa AA, Benevides NM, de Freitas Pires A, Fiuza FP, Queiroz MG, Morais TM, Pereira MG, Assreuy AM: A report of a galactan from marine alga Gelidium crinale with in vivo anti-inflammatory and antinociceptive effects. Fundam Clin Pharmacol 2013, 27(2):173-180.

65. Bitencourt Fda S, Figueiredo JG, Mota MR, Bezerra CC, Silvestre PP, Vale MR, Nascimento KS, Sampaio AH, Nagano CS, Saker-Sampaio S, et al: Antinociceptive and anti-inflammatory effects of a mucin-binding agglutinin isolated from the red marine alga Hypnea cervicornis. Naunyn Schmiedebergs Arch Pharmacol 2008, 377(2):139-148.

66. Silva LM, Lima V, Holanda ML, Pinheiro PG, Rodrigues JA, Lima ME, Benevides NM: Antinociceptive and anti-inflammatory activities of lectin from marine red alga Pterocladiella capillacea. Biol Pharm Bull 2010, 33(5):830-835

67. Lavy A, Naveh Y, Coleman R, Mokady S, Werman MJ: Dietary Dunaliella bardawil, a beta-carotene-rich alga, protects against acetic acid-induced small bowel inflammation in rats. Inflamm Bowel Dis 2003, 9(6):372-379.

68. Jin DQ, Lim CS, Sung JY, Choi HG, Ha I, Han JS: Ulva conglobata, a marine algae, has neuroprotective and anti-inflammatory effects in murine hippocampal and microglial cells. Neurosci Lett 2006, 402(1-2):154-158

69. Margret RJ, Kumaresan S, Ravikumar S: A preliminary study on the antiinflammatory activity of methanol extract of Ulva lactuca in rat. J Environ Biol 2009, 30(5 Suppl):899-902.

70. Renju GL, Muraleedhara Kurup G, Saritha Kumari CH: Anti-inflammatory activity of lycopene isolated from Chlorella marina on Type II Collagen induced arthritis in Sprague Dawley rats. Immunopharmacol Immunotoxicol 2013, 35(2):282-291.

71. Caroprese M, Albenzio M, Ciliberti MG, Francavilla M, Sevi A: A mixture of phytosterols from Dunaliella tertiolecta affects proliferation of peripheral blood mononuclear cells and cytokine production in sheep. Vet Immunol Immunopathol 2012, 150(1-2):27-35.
72. Bitencourt MA, Dantas GR, Lira DP, Barbosa-Filho JM, de Miranda GE, Santos BV, Souto JT: Aqueous and methanolic extracts of Caulerpa mexicana suppress cell migration and ear edema induced by inflammatory agents. Mar Drugs 2011, 9(8):1332-1345.

73. Vanderlei ES, Patoilo KK, Lima NA, Lima AP, Rodrigues JA, Silva LM, Lima ME, Lima V, Benevides NM: Antinociceptive and anti-inflammatory activities of lectin from the marine green alga Caulerpa cupressoides. Int Immunopharmacol 2010, 10(9):1113-1118.

74. Rodrigues JA, Vanderlei ES, Silva LM, Araujo IW, Queiroz IN, Paula GA, Abreu TM, Ribeiro NA, Bezerra MM, Chaves HV, et al: Antinociceptive and antiinflammatory activities of a sulfated polysaccharide isolated from the green seaweed Caulerpa cupressoides. Pharmacol Rep 2012, 64(2):282-292.

75. Kim SK, Lee DY, Jung WK, Kim JH, Choi I, Park SG, Seo SK, Lee SW, Lee CM, Yea SS, et al: Effects of Ecklonia cava ethanolic extracts on airway hyperresponsiveness and inflammation in a murine asthma model: role of suppressor of cytokine signaling. Biomed Pharmacother 2008, 62(5):289-296.

76. Kim TH, Bae JS: Ecklonia cava extracts inhibit lipopolysaccharide induced inflammatory responses in human endothelial cells. Food Chem Toxicol 2010, 48(6):1682-1687.

77. Kim MM, Rajapakse N, Kim SK: Anti-inflammatory effect of Ishige okamurae ethanolic extract via inhibition of NF-kappaB transcription factor in RAW 264.7 cells. Phytother Res 2009, 23(5):628-634.

78. Medeiros VP, Queiroz KC, Cardoso ML, Monteiro GR, Oliveira FW, Chavante SF, Guimaraes LA, Rocha HA, Leite EL: Sulfated galactofucan from Lobophora variegata: anticoagulant and anti-inflammatory properties. Biochemistry (Mosc) 2008, 73(9):1018-1024

79. Paiva AA, Castro AJ, Nascimento MS, Will LS, Santos ND, Araujo RM, Xavier CA, Rocha FA, Leite EL: Antioxidant and anti-inflammatory effect of polysaccharides from Lobophora variegata on zymosan-induced arthritis in rats. Int Immunopharmacol 2011, 11(9):1241-1250.

80. Sarithakumari CH, Renju GL, Kurup GM: Anti-inflammatory and antioxidant potential of alginic acid isolated from the marine algae, Sargassum wightii on adjuvant-induced arthritic rats. Inflammopharmacology 2012 http://www.ncbi.nlm.nih.gov/pubmed/23179138

81. Kawashima T, Murakami K, Nishimura I, Nakano T, Obata A: A sulfated polysaccharide, fucoidan, enhances the immunomodulatory effects of lactic acid bacteria. Int J Mol Med 2012, 29(3):447-453.

82. Siqueira RC, da Silva MS, de Alencar DB, Pires Ade F, de Alencar NM, Pereira MG, Cavada BS, Sampaio AH, Farias WR, Assreuy AM: In vivo antiinflammatory effect of a sulfated polysaccharide isolated from the marine brown algae Lobophora variegata. Pharm Biol 2011, 49(2):167-174.

83. Dore CM, Faustino Alves MG, Will LS, Costa TG, Sabry DA, de Souza Rego $L A$, Accardo CM, Rocha HA, Filgueira LG, Leite EL: A sulfated polysaccharide, fucans, isolated from brown algae Sargassum vulgare with anticoagulant, antithrombotic, antioxidant and anti-inflammatory effects. Carbohydr Polym 2013, 91(1):467-475.

84. Farias WR, Lima PC, Rodriques NV, Siqueira RC, Amorim RM, Pereira MG, Assreuy AM: A novel antinociceptive sulphated polysaccharide of the brown marine alga Spatoglossum schroederi. Nat Prod Commun 2011, 6(6):863-866.

85. Heo SJ, Yoon WJ, Kim KN, Ahn GN, Kang SM, Kang DH, Affan A, Oh C, Jung WK, Jeon YJ: Evaluation of anti-inflammatory effect of fucoxanthin isolated from brown algae in lipopolysaccharide-stimulated RAW 264.7 macrophages. Food Chem Toxicol 2010, 48(8-9):2045-2051.

86. Kim SK, Himaya SW: Medicinal effects of phlorotannins from marine brown algae. Adv Food Nutr Res 2011, 64:97-109.

87. Yoon WJ, Heo SJ, Han SC, Lee HJ, Kang GJ, Kang HK, Hyun JW, Koh YS, Yoo ES: Anti-inflammatory effect of sargachromanol $\mathrm{G}$ isolated from Sargassum siliquastrum in RAW 264.7 cells. Arch Pharm Res 2012, 35(8):1421-1430.

88. Kim MM, Kim SK: Effect of phloroglucinol on oxidative stress and inflammation. Food Chem Toxicol 2010, 48(10):2925-2933.

89. Shih CM, Cheng SN, Wong CS, Kuo YL, Chou TC: Antiinflammatory and antihyperalgesic activity of C-phycocyanin. Anesth Analg 2009, 108(4):1303-1310.

90. Lee JC, Son YO, Pratheeshkumar P, Shi X: Oxidative stress and metal carcinogenesis. Free Radic Biol Med 2012, 53(4):742-757.

91. Kongara S, Karantza V: The interplay between autophagy and ROS in tumorigenesis. Frontiers in oncology 2012, 2:171.

92. Park SH, Ozden O, Jiang H, Cha Yl, Pennington JD, Aykin-Burns N, Spitz DR, Gius D, Kim HS: Sirt3, mitochondrial ROS, ageing, and carcinogenesis. In J Mol Sci 2011, 12(9):6226-6239. 
93. Okoh V, Deoraj A, Roy D: Estrogen-induced reactive oxygen speciesmediated signalings contribute to breast cancer. Biochim Biophys Acta 2011, 1815(1):115-133.

94. Aykin-Burns N, Ahmad IM, Zhu Y, Oberley LW, Spitz DR: Increased levels of superoxide and $\mathrm{H} 2 \mathrm{O} 2$ mediate the differential susceptibility of cancer cells versus normal cells to glucose deprivation. Biochem J 2009, 418(1):29-37.

95. Fayyaz S, Faroogi AA: miRNA and TMPRSS2-ERG do not mind their own business in prostate cancer cells. Immunogenetics 2013, 65(5):315-332.

96. Faroogi AA, Fayyaz S, Rashid S: Upon the tightrope in prostate cancer: two acrobats on the same tightrope to cross the finishline. Mol Cell Biochem 2012, 364(1-2):53-57.

97. Dutta KK, Zhong Y, Liu YT, Yamada T, Akatsuka S, Hu Q, Yoshihara M, Ohara $H$, Takehashi M, Shinohara T, et al: Association of microRNA-34a overexpression with proliferation is cell type-dependent. Cancer Sci 2007, 98(12):1845-1852.

98. Vendramini-Costa DB, Carvalho JE: Molecular link mechanisms between inflammation and cancer. Curr Pharm Des 2012, 18(26):3831-3852.

99. Poehlmann A, Kuester D, Malfertheiner P, Guenther T, Roessner A: Inflammation and Barrett's carcinogenesis. Pathol Res Pract 2012, 208(5):269-280

100. Martin-Cordero C, Leon-Gonzalez AJ, Calderon-Montano JM, Burgos-Moron E, Lopez-Lazaro M: Pro-oxidant natural products as anticancer agents. Curr Drug Targets 2012, 13(8):1006-1028.

101. Faroogi AA, Butt G, Razzaq Z: Algae extracts and methyl jasmonate anticancer activities in prostate cancer: choreographers of 'the dance macabre'. Cancer Cell Int 2012, 12(1):50.

102. Yen CY, Chiu CC, Haung RW, Yeh CC, Huang KJ, Chang KF, Hseu YC, Chang FR, Chang HW, Wu YC: Antiproliferative effects of goniothalamin on Ca922 oral cancer cells through apoptosis; DNA damage and ROS induction. Mutat Res 2012, 747(2):253-258.

103. Zandi K, Tajbakhsh S, Nabipour I, Rastian Z, Yousefi F, Sharafian S, Sartavi K: In vitro antitumor activity of Gracilaria corticata (a red alga) against Jurkat and molt-4 human cancer cell lines. Afr J Biotechnol 2010, 9(40):6787-6790.

104. Zandi K, Ahmadzadeh S, Tajbakhsh S, Rastian Z, Yousefi F, Farshadpour F, Sartavi K: Anticancer activity of Sargassum oligocystum water extract against human cancer cell lines. Eur Rev Med Pharmacol Sci 2010, 14(8):669-673.

105. Yeh CC, Yang Jl, Lee JC, Tseng CN, Chan YC, Hseu YC, Tang JY, Chuang LY, Huang HW, Chang FR, et al: Anti-proliferative effect of methanolic extract of Gracilaria tenuistipitata on oral cancer cells involves apoptosis, DNA damage, and oxidative stress. BMC Complement Altern Med 2012, 12(1):142.

106. Kim JY, Yoon MY, Cha MR, Hwang JH, Park E, Choi SU, Park HR, Hwang Yl: Methanolic extracts of Plocamium telfairiae induce cytotoxicity and caspase-dependent apoptosis in HT-29 human colon carcinoma cells. J Med Food 2007, 10(4):587-593.

107. Park HY, Lim CW, Kim YK, Yoon HD, Lee KJ: Immunostimulating and anticancer activities of hot water extract from Capsosiphon fulvescens. $J$ Korean Soc Appl Biol Chem 2006, 49:343-348.

108. Kwon MJ, Nam TJ: A polysaccharide of the marine alga Capsosiphon fulvescens induces apoptosis in AGS gastric cancer cells via an IGF-IR -mediated PI3K/Akt pathway. Cell Biol Int 2007, 31(8):768-775.

109. Kim YM, Kim IH, Nam TJ: Induction of apoptosis signaling by glycoprotein of Capsosiphon fulvescens in human gastric cancer (AGS) cells. Nutr Cancer 2012, 64(5):761-769.

110. Nakajima K, Yokoyama A, Nakajima Y: Anticancer effects of a tertiary sulfonium compound, dimethylsulfoniopropionate, in green sea algae on Ehrlich ascites carcinoma-bearing mice. J Nutr Sci Vitaminol 2009, 55(5):434-438

111. Go H, Hwang HJ, Nam TJ: A glycoprotein from Laminaria japonica induces apoptosis in HT-29 colon cancer cells. Toxicol In Vitro 2010, 24(6):1546-1553.

112. Ermakova S, Sokolova R, Kim SM, Um BH, Isakov V, Zvyagintseva T: Fucoidans from brown seaweeds Sargassum hornery, Eclonia cava, Costaria costata: structural characteristics and anticancer activity. Appl Biochem Biotechnol 2011, 164(6):841-850.

113. Costa LS, Fidelis GP, Telles CB, Dantas-Santos N, Camara RB, Cordeiro SL, Costa MS, Almeida-Lima J, Melo-Silveira RF, Oliveira RM, et al: Antioxidant and antiproliferative activities of heterofucans from the seaweed Sargassum filipendula. Mar Drugs 2011, 9(6):952-966
114. Satomi Y: Fucoxanthin induces GADD45A expression and G1 arrest with SAPK/JNK activation in LNCap human prostate cancer cells. Anticancer Res 2012, 32(3):807-813.

115. Khan Z, Bhadouria P, Bisen PS: Nutritional and therapeutic potential of Spirulina. Curr Pharm Biotechnol 2005, 6(5):373-379.

116. Shih C, Teicher BA: Cryptophycins: a novel class of potent antimitotic antitumor depsipeptides. Curr Pharm Des 2001, 7(13):1259-1276.

117. Corbett TH, Valeriote FA, Demchik L, Polin L, Panchapor C, Pugh S, White K, Knight J, Jones J, Jones $L$, et al: Preclinical anticancer activity of cryptophycin-8. J Exp Ther Oncol 1996, 1(2):95-108.

doi:10.1186/1475-2867-13-55

Cite this article as: Lee et al:: Marine algal natural products with antioxidative, anti-inflammatory, and anti-cancer properties. Cancer Cell International 2013 13:55.

\section{Submit your next manuscript to BioMed Central and take full advantage of:}

- Convenient online submission

- Thorough peer review

- No space constraints or color figure charges

- Immediate publication on acceptance

- Inclusion in PubMed, CAS, Scopus and Google Scholar

- Research which is freely available for redistribution 